\title{
Microbial production of amino acid-modified spider dragline silk protein with intensively improved mechanical properties
}

Haibo Zhang, Fengli Zhou, Xinglin Jiang, Mingle Cao, Shilu Wang, Huibin Zou, Yujin Cao, Mo Xian \& Huizhou Liu

To cite this article: Haibo Zhang, Fengli Zhou, Xinglin Jiang, Mingle Cao, Shilu Wang, Huibin Zou, Yujin Cao, Mo Xian \& Huizhou Liu (2015): Microbial production of amino acid-modified spider dragline silk protein with intensively improved mechanical properties, Preparative Biochemistry and Biotechnology, DOI: 10.1080/10826068.2015.1084637

To link to this article: http://dx.doi.org/10.1080/10826068.2015.1084637

View supplementary material ¿

曲 Accepted online: 13 Oct 2015.

Submit your article to this journal ๘

Џll Article views: 3

Q View related articles ¿

View Crossmark data $₫$ 


\title{
Microbial production of amino acid-modified spider dragline silk protein with intensively improved mechanical properties
}

Haibo Zhang ${ }^{1}$, Fengli Zhou ${ }^{1}$, Xinglin Jiang ${ }^{1}$, Mingle $\mathrm{Cao}^{2}$, Shilu Wang ${ }^{1}$, Huibin Zou ${ }^{1}$, Yujin $\mathrm{Cao}^{1}$, Mo Xian ${ }^{1}$, Huizhou Liu ${ }^{1}$

${ }^{1}$ CAS Key Laboratory of Biobased Materials, Qingdao Institute of Bioenergy and Bioprocess Technology, Chinese Academy of Sciences, China ${ }^{2}$ University of Marburg, Marburg, Germany

Corresponding author: Mo Xian and Huizhou Liu, Address: CAS Key Laboratory of Biobased Materials, Qingdao Institute of Bioenergy and Bioprocess Technology, Chinese Academy of Sciences, No. 189 Songling Road, Laoshan District, Qingdao 266101, P. R. China.Email: xianmo@qibebt.ac.cn, Liuhz@qibebt.ac.cn

\begin{abstract}
Spider dragline silk is a remarkably strong fiber with impressive mechanical properties, which were thought to be resulted from the specific structures of the underlying proteins and their molecular size. In this study, a silk protein 11R26 from the dragline silk protein of Nephila clavipes was used to analyze the potential effects of the special amino acids on the function of 11R26. Three protein derivatives ZF4, ZF5 and ZF6 were obtained by site-directed mutagenesis, based on the sequence of 11R26, and among these derivatives, serine was replaced with cysteine, isoleucine and arginine, respectively. After being expressed and purified the mechanical performance of the fibers derived from the four proteins was tested. Both hardness and average elastic modulus of ZF4 fiber increased 2.2 times compared with those of 11R26. The number of disulfide bonds in ZF4 protein
\end{abstract}


was 4.67 times to that of 11R26, which implied that disulfide bonds outside the poly-Ala region affect the mechanical properties of spider silk more efficiently. The results indicated that the mechanical performances of spider silk proteins with small molecular size can be enhanced by modification of the amino acids residues. Our research has not only made the feasibility for large-scale production of spider silk proteins but also provides valuable information for protein rational design.

Keywords: Nephila clavipes, Escherichia coli, heterogenous expression, rational design, spider silk protein

\section{INTRODUCTION}

Spider silk is a fascinating natural fiber with outstanding mechanical properties, tissue compatibility-, and is considered to be perfectly suitable for biomedicines, biomaterials, textiles and military equipments. ${ }^{[1-3]}$ Among various silks, the dragline silk is the bestcharacterized one, and its remarkable mechanical properties, including high toughness, tensile strength and elasticity, exceed those of most other natural and synthetic materials such as synthetic rubber, Kevlar or high-tensile steel. ${ }^{[4-7]}$

Dragline silk is composed of two main silk proteins, both of which are characterized by highly repetitive motifs consisting of distinct, single-oligopeptide sequence blocks and 
with a high content of alanine, glycine or proline. Generally, the amino acid composition and the number of blocks are responsible for the performance of the silk. ${ }^{[8]}$ Therefore, the properties of spider silk can be directly modified by altering the primary structure of the silk protein via redesigning the corresponding silk gene's sequence. ${ }^{[9]}$

During the past several years, progress has been made in the genetic engineering of the spider-silk proteins and its expression hosts. Silk proteins with various molecular weights were yielded by multimerization of the repetitive monomer sequences of natural genes. ${ }^{[10-13]}$ A series of synthetic dragline silk-like genes that incorporated codons for methionine flanking the polyalanine regions present in the consensus sequence of spider dragline silk protein, were constructed, cloned and expressed, and the solubility of spider silk was increased up to some extent. ${ }^{[14,15]}$ Enzymatic phosphorylation has been also employed to control the solution structure of a silk protein. In the experiment, the $\beta$ sheet-forming domain of the recombinant silk protein has been modified by incorporating a phosphorylation site (Arg-Gly-Tyr-Ser-Leu-Gly) for cyclic AMP-dependent protein kinase (cAPK). In the phosphorylated state, the newly added phosphate groups could impair the formation of the $\beta$-sheets thereby improving protein solubility ${ }^{[15-18]}$. Incorporation of amino acids and chemical modification of silk protein amino acid with side chains containing thiols, amino, or carboxyl groups, ${ }^{[19,20]}$ like lysine or cysteine, is 
supposed to be feasible, since this allows side-specific functionalization of the silk proteins. ${ }^{[3,21]}$

Although a lot of research has been performed on recombinant spider silk proteins but some problems still remain unresolved. The spider silk proteins consist largely of glycine, alanine and highly repetitive sequences, which hinder their high expression in fastgrowing microorganisms such as yeast or bacteria. This phenomenon is more apparent when the big size spider silk protein has been expressed. ${ }^{[22]}$ One disadvantage that low concentration of larger silk proteins in an aqueous system also turns to be a limitation in the process of spinning. ${ }^{[2]}$ Meanwhile, the mechanical properties of the fibers derived from smaller silk protein have been found to be declined. ${ }^{[23]}$ It is supposed that the modification of silk protein amino acids with side chains could be used to produce functional silk proteins. ${ }^{[3,21]}$ Therefore, biosynthesis of small molecular silk proteins with improved mechanicals is a perspective way to solve these problems. Grip et al. introduced AA to substitute for CC in the poly-Ala block of an Euprosthenops australis MaSp1 fragment, which increased the stiffness and tensile strength (about 40\%) without changes in ability to form fibers, or in fiber morphology. ${ }^{[24,25]}$ Meanwhile, replacement of Cys with a Ser in the nonrepetitive C-terminal domain did not interfere with dimerization, fiber morphology or tensile strength. However, the poly-Ala blocks are thought to form $\beta$-sheets in the silk fibers adjacent Cys side-chains will point in opposite 
directions, which was assumed to maximize the chances of forming intermolecular disulfides, and the $\beta$-sheets played an important part in the mechanical properties.

In this study, three mutant proteins were obtained, based on the sequence of the wild type protein 11R26, which was from the dragline silk protein of $N$. clavipes. ${ }^{[26]}$ The four proteins were all expressed in E. coli BL21(DE3), purified and spun into fibers. Finally, the mechanical properties of the fibers were tested to analyze the potential effects of special amino acids on the function of the silk proteins.

\section{MATERIALS AND METHODS}

\section{Plasmids and Stains}

T4 DNA ligase, restriction enzymes, $\beta$-isopropylthiogalactoside (IPTG), DNA molecular weight standards, agarose for electrophoresis, the cloning vector $\mathrm{pMD18-T}$ and expression plasmid pET30a were purchased from TaKaRa Biotechnology (Dalian) Co., Ltd. E. coli strains JM109 and BL21 (DE3) were purchased from Beijing Transgen Biotechnology Co., Ltd.

\section{Gene and Mutagenesis}

The protein sequence of 11R26 contains three repeats of the consensus amino acid sequence (SGRGGLGGQGAGAAAAAGGAGQGGYGGLGSQG) from $N$. clavipes 
dragline silk protein [25]. Three 11R26 protein derivatives, ZF4, ZF5 and ZF6 were obtained by site-directed mutagenesis, based on the amino acid sequence of 11R26, and their repetitive motifs. The gene sequence were analyzed by online software (http://www.genscript.com/cgi-bin/tools/rare_codon_analysis) and optimized to the preferred codon usage of E. coli (http://www.jcat.de/). The optimized genes (Sequence1Sequence4) were synthesized by Generay Company with plasmid pET30a as the vector.

\section{Protein Expression and Purification}

E. coli BL21(DE3) cells transformed with the respective expression vectors were inoculated into $5 \mathrm{ml}$ of $\mathrm{Kan} / \mathrm{LB}$ medium $\left(37^{\circ} \mathrm{C}\right.$, $\left.180 \mathrm{rpm}\right)$. The $5 \mathrm{ml}$ of overnight culture was then inoculated to $100 \mathrm{ml}$ of fresh medium, which was used as the seed of $2 \mathrm{~L} / 5 \mathrm{~L}$ fermentation Kan/LB medium. Fed batch fermentation process was optimized mainly by feeding glucose and LB medium. The feedstocks added were glucose, glucose/LB medium and LB medium corresponding to an $\mathrm{OD}_{600}$ of $\sim 10-80, \sim 80-120$ and over 120 , respectively. The cultures were induced by adding IPTG at an $\mathrm{OD}_{600}$ of 100 . Cell pellets were harvested at $\mathrm{OD}_{600}$ of 150 , resuspended in lysis buffer $\left(100 \mathrm{mM} \mathrm{NaH}{ }_{2} \mathrm{PO}_{4}, 10 \mathrm{mM}\right.$

Tris- $\mathrm{HCl}$ (pH 7.5), $10 \mathrm{mM}$ Imidazole, $6 \mathrm{M}$ Urea), and lysed by ultrasonic disintegration (130 kHz, 1 h) on ice, using an HD/UW2200/KE76 ultrasonicator (Bandelin, Berlin, Germany). 
Cell homogenate was centrifuged at 30,000 g for $1 \mathrm{~h}$. The supernatant was filtered through $0.22 \mu \mathrm{m}$ membrane (Millipore) and loaded onto a $5 \mathrm{ml} \mathrm{Ni-NTA}$ spin column (Ni Sepharose $^{\mathrm{TM}} 6$ Fast Flow, $2 \mathrm{ml} / \mathrm{min}$, GE Healthcare). The column was first equilibrated with $15 \mathrm{ml}$ of binding buffer $\left(100 \mathrm{mM} \mathrm{NaH} \mathrm{PO}_{4}, 10 \mathrm{mM}\right.$ Tris-HCl, $10 \mathrm{mM}$ Imidazole, 6 M Urea), and the concentrated proteins were loaded onto the column before the column was washed twice with $15 \mathrm{ml}$ of washing buffer $\left(100 \mathrm{mM} \mathrm{NaH}_{2} \mathrm{PO}_{4}, 10 \mathrm{mM}\right.$ Tris- $\mathrm{HCl}$, $20 \mathrm{mM}$ Imidazole, $6 \mathrm{M}$ Urea) to remove non-specific proteins. His-tagged recombinant protein was eluted with $15 \mathrm{ml}$ of elution buffer $\left(100 \mathrm{mM} \mathrm{NaH}_{2} \mathrm{PO}_{4}, 10 \mathrm{mM}\right.$ Tris-HCl, $250 \mathrm{mM}$ Imidazole, $6 \mathrm{M}$ Urea). Finally, the concentration of the eluted protein was determined using the Bradford protein assay (Bio-Rad, USA). An aliquot of the purified 6xHis-tagged protein (about $10 \mu \mathrm{L}$ ) was analysed by SDS-PAGE.

\section{Electrospinning and Electron Microscope}

The purified 11R26 protein was dialyzed with $\mathrm{ddH}_{2} \mathrm{O}$, freeze-dried and dissolved in HFIP at three different concentrations of $50 \mathrm{mg} / \mathrm{mL}, 80 \mathrm{mg} / \mathrm{mL}$ and $100 \mathrm{mg} / \mathrm{mL}$ at $50^{\circ} \mathrm{C}$ for 12 $\mathrm{h}$ to obtain a homogeneous solution, which was loaded into a $1 \mathrm{~mL}$ syringe and electrospun into nanofibers. Other proteins were electrospun as described above.

\section{Characterization of Mechanical Properties}


Mechanical properties of the nanofibers were precisely measured using an atomic force microscope (harmoniX mode). Elastic modulus and force curves of hardness were analyzed with the software HARMONIX.

\section{Determination of Disulfide Bonds}

The numbers of disulfide bonds in wild type protein 11R26 and mutant ZF4 were determined by a spectrophotometric method. Firstly, the protein concentration was adjusted to $10 \mathrm{mg} / \mathrm{mL}$, and then $1 \mathrm{~mL}$ of the protein solution was diluted to $20 \mathrm{ml}$ with buffer A (8 M Urea, 3 mM EDTA, 1\% SDS and 0.2 M Tris-HC1, pH8.0), and buffer D (8 M Urea, 3 mM EDTA, 1\% SDS, 0.1 $\mathrm{M} \mathrm{Na}_{2} \mathrm{SO}_{3}, 0.2 \mathrm{M}$ Tris-HC1, pH8.0). $0.1 \mathrm{~mL}$ of buffer B (10 mM dithionitrobenzoic acid (DTNB), 0.2 M Tris-HC1, pH8.0) was added to $3 \mathrm{~mL}$ of protein solution diluted with buffer $\mathrm{A}$ and the absorbance at $412 \mathrm{~nm}$ was measured after $30 \mathrm{~min}$ incubation in comparison with the reagent blank control. $0.1 \mathrm{ml}$ of buffer C (8 M Urea, 3 mM EDTA, $1 \%$ SDS, $0.1 \mathrm{M} \mathrm{Na}_{2} \mathrm{SO}_{3}, 10 \mathrm{mM}$ 2-nitro-5thiosulfobenzoate (NTSB) and 0.2 M Tris-HC1, pH9.5) was added to $3 \mathrm{ml}$ of solution diluted with buffer $\mathrm{D}$ and the absorbance at $412 \mathrm{~nm}$ was monitored after $30 \mathrm{~min}$ incubation, and the control was detected at the same conditions.

\section{RESULTS}

\section{Design of Amino Acid Sequences}


The silk protein 11R26 contains three repeats of the consensus amino acid sequence (SGRGGLGGQGAGAAAAAGGAGQGGYGGLGSQG) of $N$. clavipes dragline silk protein [25] with a molecular mass of about $18 \mathrm{kDa}$. Three $11 \mathrm{R} 26$ protein derivatives, ZF4, ZF5 and ZF6 were obtained by site-directed mutagenesis, based on the amino acid sequence of 11R26, and their repetitive motifs were shown in Table 1. In ZF4, cysteine was substituted for serine to increase the disulfide bonds in- and inter- the spider silk proteins. In ZF5, serine was converted into isoleucine to increase the content of the branched-chain amino acids in the protein. And in ZF6, serine was replaced with arginine to increase the hydrogen bond in- and inter- the proteins.

The four protein sequences were reverse transcribed into nucleotides, adapted to E. coli's codon usage. The gene segments were synthesized directly and inserted into the expression vector pET30a in-framely, to yield plasmids expressing $6 \times$ His-tagged recombinant proteins.

Optimization of Fermentation Process and Protein Purification

As the spider silk proteins consist largely of glycine, alanine and highly repetitive sequences, the yield of recombinant proteins is always hindered in fast-growing microorganisms, especially for the big-size proteins. ${ }^{[1,26]}$ To achieve high cell yields and thereby improve the production of protein 11R26 along with its three derivatives, the fed 
batch fermentation process was optimized. It was found that, a higher $\mathrm{OD}_{600}$ of fermentation has been achieved mainly by adding different feedstocks at different stage. The feedstocks added were glucose, glucose/LB medium and LB medium corresponding to an $\mathrm{OD}_{600}$ of $\sim 10-80, \sim 80-120$ and over 120 , respectively. The cultures were induced at an $\mathrm{OD}_{600}$ of 100 by adding $0.5 \mu \mathrm{M}$ IPTG and subsequently harvested at an $\mathrm{OD}_{600}$ of 150 . The recombinant proteins were purified to be electrophoretic homogeneity by Ni affinity chromatography. SDS-PAGE analysis showed that the four purified proteins (11R26, ZF4, ZF5 and ZF6), had molecular mass of $18.0 \mathrm{kDa}$ (Supplemental Fig. 1), and their concentration is approximately $1.5 \mathrm{~g} / \mathrm{L}$, determined by a nanovue spectrophotometer (USA), using bovine serum albumin as standard.

\section{Electrospinning and Electron Microscope}

To determine the proper protein concentration for electrospinning, the wild type 11R26

protein was tested. 11R26 protein cannot be electrospun into nanofibers at the concentration of $50 \mathrm{mg} / \mathrm{mL}$ (Fig. 2A), while inhomogeneous nanofibers were formed at the concentration of $80 \mathrm{mg} / \mathrm{mL}$. When the protein concentration reached $100 \mathrm{mg} / \mathrm{mL}$, homogeneous nanofibers were obtained (Fig. 2C). Therefore, all the mutants were electrospun at the optimal concentration of $100 \mathrm{mg} / \mathrm{mL}$. Scanning electron microscopy revealed that the diameters of the four nanofibers were about $1 \sim 2 \mu \mathrm{m}$ (Supplemental Fig. 
S1), and no difference was evident among them, so their mechanical performance could be comparable in the following experiments.

\section{Characterizations of Mechanical Properties}

Hardness and elastic modulus are the main properties in the nanofibers' mechanical testing. In the hardness testing, ZF4 has a value 3.2 as high as that of 11R26, while ZF5/ZF6 showed slight changes compared to 11R26 (Fig. 3).

The elastic modulus of ZF4 was mainly above $0.8 \mathrm{GPa}$, and the maximum was about 2.312 $\mathrm{GPa}$ while the average was $1.347 \mathrm{GPa}$ (Fig. 4B). As for the wild type 11R26, the respective values were $0.6 \mathrm{GPa}, 1.385 \mathrm{GPa}$ and $0.421 \mathrm{GPa}$ (Fig. 4A). The average elastic modulus of ZF4 was also 3.2 times as high as that of 11R26. The other mutants were found similar to the control (Fig. 4). These results indicated that the hardness and elasticity of ZF4 nanofibers were better than those of the others, which might be caused by the larger numbers of disulfide bonds formed by cysteines.

\section{Measurement of Disulfide Bonds}

To verify the speculation, the numbers of disulfide bonds in ZF4 and 11R26 were determined by spectrophotometry method. Free thiols can react with DTNB and NTSB, and the product NTB can be detected at the absorbance of $412 \mathrm{~nm}$. By detecting the free 
and total thiols before and after $\mathrm{Na}_{2} \mathrm{SO}_{3}$ treatment, the number of disulfide bonds of the ZF4 was determined to be $24.35 \mu \mathrm{mol} / \mathrm{g}$ with an increase of 3.67 times, compared with 11R26 with the number of $5.21 \mu \mathrm{mol} / \mathrm{g}$. Our results suggest that the disulfide bonds might enhance the mechanical performance of the spider silk proteins.

\section{DISCUSSION}

In this study, the spider silk protein 11R26 and its three derivatives were expressed in the fast-growing host E. coli BL21(DE3), and the various conditions for fermentation process were optimized. The recombinant proteins were purified and spun into fibers, and the mechanical characteristics of the fibers were tested.

The special sequence features of spider silk proteins limit their production of high molecular weight protein in fast-growing microorganisms. ${ }^{[2,27]}$ Size of a recombinant dragline silk protein is thought to be a key factor in controlling the mechanical properties of the fiber produced. Numerous studies have been focused on increasing the yield of the high molecular weight spider silk proteins, including genetic modification of the host. In previous studies, the dragline spider silk gene sequence has been designed, synthesized and expressed in E. coli with the production of $20 \mathrm{mg} / \mathrm{L}$ protein. ${ }^{[28]}$ The gene of spider silk MaSp2 protein has been expressed in E. coli with the production of $10 \mathrm{mg} / \mathrm{g}$ wet weight of the cell (about $100 \mathrm{mg} / \mathrm{L}$ ) ${ }^{[29]}$ whereas the co-expression of MaSp1 and MaSp2 
protein reached to $300 \mathrm{mg} / \mathrm{L} .{ }^{[30]}$ Genetically modified E. coli was used to express about $0.5 \mathrm{~g} / \mathrm{L}$ native-sized dragline silk protein ${ }^{[22]}$. In this study, the fermentation process was optimized to produce the small-sized spider silk protein in the common E. coli BL21(DE3) and approximately $1.5 \mathrm{~g} / \mathrm{L}$ protein was produced, which was two-folds higher than the previously reported. The application of genetically modified host might further improve the production titer of the protein.

The purified recombinant proteins had been electrospun into nanofibers, and the mechanical properties were tested, which showed that the hardness of the mutant ZF4 was 2.2 fold higher compared with that of wild type $11 \mathrm{R} 26$, whereas slight change was observed in ZF5/ZF6 mutant. The variations observed in elastic modulus map were compared and two fold increase in ZF4 value was observed as compared to that of wild type 11R26. The number of disulfide bonds of the ZF4 mutant was increased up to 3.67 folds compared with the wild type, suggesting the mechanical improvement is related to the number of disulfide bonds. Although the addition of branched-chain amino acid (ZF5) and arginine (ZF6) did not cause enormous changes to the mechanical properties of the protein, the results of ZF4 indicated that the mechanical properties of the recombinant proteins can be improved by modifying the wild type protein. Grip et al. found that the interconnecting force between $\beta$-sheets play an important part in the stiffness of the fibers. Introduction of AA to substitute for CC in the poly-Ala block increased the 
stiffness and tensile strength (about $40 \%$ ) without changes in fiber morphology. ${ }^{[25]}$ This study implies that the interconnecting force outside the poly-Ala region in the repetitive sequences affect the mechanical properties of spider silk more efficiently.

The mechanical properties of a variety of natural silk protein fibers have previously been investigated by many researchers. The elastic modulus of elastin (bovine ligament), resilin (Dragonfly tendon), collagen (Mammalian tendon), mussel byssus, distal (Mytilus californianus), mussel byssus, proximal (M. californianus), dragline silk (Araneus diadematus), viscid silk (A. diadematus) and Kevlar silk proteins were determined to be $0.0011,0.002,1.2,0.87,0.016,10,0.003$ and $130 \mathrm{Gpa} .{ }^{[31]}$ In this study, we obtained the elastic modulus of the mutants ZF4 and ZF5 (three copies) to be 1.347 and 0.953 Gpa respectively, higher than the elastic modulus of most natural silk proteins. But the elastic modulus of the recombinant protein was lower than the natural spider silk from $A$. diadematus, because the expressed recombination protein with a molecular weight of $18.0 \mathrm{kDa}$ was much lower than the natural one $(250 \sim 300 \mathrm{kDa})$, the difference of electrospun conditions and diameter of the fiber maybe another reason. ${ }^{[32,33]}$ However, heterogenous expressions of repetitive sequences of large size proteins possess the difficulty of genetic instability and size heterogeneity of their products, both of which hindered the expression of high molecular weight protein at high level. ${ }^{[30]}$ Meanwhile, small molecular weight proteins do not possess these problems, but their mechanical 
properties are much lower. In this study, we made a single amino acid modification to the spider silk protein at serine site (table 1) of the wild type protein to gain small size protein $(18.0 \mathrm{kDa})$, and these recombinant proteins with improved mechanical properties were proved to be correctly expressed in fast-growing host $E$. coli BL21(DE3), which would be helpful to resolve the problem of producing high mechanical properties spider silk proteins in E. coli with high yield.

\section{CONCLUSIONS}

In summary, it was found that the mechanical performance of spider silk proteins with small molecular size can be enhanced efficiently by modification of the amino acids residues, which is outside the poly-Ala region in the repetitive sequences. Our study has provided the basis to produce small proteins in fast-growing host efficiently with higher yield, and their hydrophilic property is more suitable for spinning process, compared to those of the proteins with larger size. Our research has paved the way for future largescale production of spider silk proteins, and also provided valuable information for protein rational design.

\section{ACKNOWLEDGEMENTS}

We are grateful to Dr. Zahid Hussain (Tobacco Research Institute, Chinese Academy of Agricultural Sciences) for the manuscript modification. This work was supported by the 
Knowledge Innovation Program of the Chinese Academy of Sciences (No. Y112131105), National Natural Science Foundation of China (NSF No. 31400084), Natural Science Foundation of Shandong Province ( No. ZR2014CQ008),

Taishan Scholars Climbing Program of Shandong (No.tspd20150210) .

\section{REFERENCES}

1. Lammel, A.;M. Schwab;M. Hofer;G. Winter;T. Scheibel, Recombinant spider silk particles as drug delivery vehicles. Biomaterials 2011, 32(8), 2233-2240.

2. Slotta, U.;N. Mougin;L. Römer;A.H. Leimer, Synthetic spider silk proteins and threads. Chem. Eng. Progress 2012, 108(5), 43-49.

3. Vendrely, C.;T. Scheibel, Biotechnological production of spider-silk proteins enables new applications. Macromol. Biosci. 2007, 7(4), 401-409.

4. Gosline, J.;P. Guerette;C. Ortlepp;K. Savage, The mechanical design of spider silks: from fibroin sequence to mechanical function. J. Exp. Biol. 1999, 202(23), 3295-3303.

5. Heim, M.;C.B. Ackerschott;T. Scheibel, Characterization of recombinantly produced spider flagelliform silk domains. J. Struct. Biol. 2010, 170(2), 420-425.

6. Heim, M.;D. Keerl;T. Scheibel, Spider silk: from soluble protein to extraordinary fiber. Angew. Chem. Int. Edit. 2009, 48(20), 3584-3596.

7. Suh, H., Recent advances in biomaterials. Yonsei Med. J. 1998, 39, 87-96. 
8. Rising, A.;M. Widhe;J. Johansson;M. Hedhammar, Spider silk proteins: recent advances in recombinant production, structure-function relationships and biomedical applications. Cel. Mol. Life. Sci. 2011, 68(2), 169-184.

9. Fukushima, Y., Genetically engineered syntheses of tandem repetitive polypeptides consisting of glycine-rich sequence of spider dragline silk. Biopolymers 1998, 45(4), 269279.

10. Foo, C.W.P.;D.L. Kaplan, Genetic engineering of fibrous proteins: spider dragline silk and collagen. Adv. Drug Delivery. Rev. 2002, 54(8), 1131-1143.

11. Top, A.;K.L. Kiick, Multivalent protein polymers with controlled chemical and physical properties. Adv. Drug Delivery. Rev. 2010,62(15), 1530-1540.

12. Winkler, S.;S. Szela;P. Avtges;R. Valluzzi;D.A. Kirschner;D. Kaplan, Designing recombinant spider silk proteins to control assembly. Int. J. Biol. Macromol. 1999, 24(23), 265-270.

13. Zhou, Y.;S. Wu;V.P. Conticello, Genetically directed synthesis and spectroscopic analysis of a protein polymer derived from a flagelliform silk sequence.

Biomacromolecules 2001, 2(1), 111-125.

14. Haider, M.;Z. Megeed;H. Ghandehari, Genetically engineered polymers: status and prospects for controlled release. J. Control. Release 2004, 95(1), 1-26. 
15. Szela, S.;P. Avtges;R. Valluzzi;S. Winkler;D. Wilson;D. Kirschner;D.L. Kaplan, Reduction-oxidation control of $\beta$-sheet assembly in genetically engineered silk.

Biomacromolecules 2000, 1(4), 534-542.

16. Winkler, S.;D. Wilson;D. Kaplan, Controlling $\beta$-sheet assembly in genetically engineered silk by enzymatic phosphorylation/dephosphorylation. Biochemistry 2000, 39(41), 12739-12746.

17. Valluzzi, R.;S. Szela;P. Avtges;D. Kirschner;D. Kaplan, Methionine redox controlled crystallization of biosynthetic silk spidroin. J. Phys. Chem. B 1999, 103(51), 11382-

11392.

18. Valluzzi, R.;S. Winkler;D. Wilson;D.L. Kaplan, Silk: molecular organization and control of assembly. Philos. T. R. Soc. B. 2002, 357(1418), 165-167.

19. Huemmerich, D;; U. Slotta;T. Scheibel, Processing and modification of films made from recombinant spider silk proteins. Appl. Phy. A: Mater. 2006, 82(2), 219-222.

20. Zhou, C.Z.;F. Confalonieri;N. Medina;Y. Zivanovic;C. Esnault;T. Yang;M. Jacquet;J. Janin;M. Duguet;R. Perasso;Z.G. Li, Fine organization of Bombyx mori fibroin heavy chain gene. Nucleic Acids Res. 2000, 28(12), 2413-2419.

21. Thomas, S., Protein fibers as performance proteins: new technologies and applications. Curr. Opin. Biotechnol. 2005, 16(4), 427-433. 
22. Xia, X.;Z. Qian;C.S. Ki;Y.H. Park;D.L. Kaplan;S.Y. Lee, Native-sized recombinant spider silk protein produced in metabolically engineered Escherichia coli results in a strong fiber. P. Nat. A. S. 2010, 107(32), 14059-14063.

23. Vencatesan Renugopalakrishnan;R.V. Lewis, Bionanotechnology: proteins to nanodevices. 2006, Netherlands: Springer.

24. Stark, M.;S. Grip;A. Rising;M. Hedhammar;W. Engström;G. Hjälm;J. Johansson, Macroscopic fibers self-assembled from recombinant miniature spider silk proteins. Biomacromolecules 2007, 8(5), 1695-1701.

25. Grip, S.;J. Johansson;M. Hedhammar, Engineered disulfides improve mechanical properties of recombinant spider silk. Protein Sci. 2009, 18(5), 1012-1022.

26. Foo, C.W.P.;E. Bini;J. Huang;S. Lee;D. Kaplan, Solution behavior of synthetic silk peptides and modified recombinant silk proteins. App. Phys. A: Mater. 2006, 82(2), 193203.

27. Teulé, F.;Y.G. Miao;B.H. Sohn;Y.S. Kim;J.J. Hull;M.J. Fraser;R.V. Lewis;D.L. Jarvis, Silkworms transformed with chimeric silkworm/spider silk genes spin composite silk fibers with improved mechanical properties. P. Nat. A.S. 2012, 109, 923-928.

28. Arcidiacono, S.;C. Mello;D. Kaplan;S. Cheley;H. Bayley, Purification and characterization of recombinant spider silk expressed in Escherichia coli. Appl. Microbiol. Biotechnol. 1998, 49(1), 31-38. 
29. Lewis, R.V.;M. Hinman;S. Kothakota;M.J. Fournier, Expression and purification of a spider silk protein: a new strategy for producing repetitive proteins. Protein Expr. Purif. 1996, 7(4), 400-406.

30. Fahnestock, S.R.;S.L. Irwin, Synthetic spider dragline silk proteins and their production in Escherichia coli. Appl. Microbiol. Biotechnol. 1997, 47(1), 23-32.

31. Gordon, J.E., The science of structures and materials. 1988, W. H. Freeman and Co, 41 Madison Avenue: New York 10010, USA.

32. Gosline, J.M.;M.E. DeMont;M.W. Denny, The structure and properties of spider silk. Endeavour 1986, 10(1), 37-43.

33. Vollrath, F.;D. Knight, Structure and function of the silk production pathway in the spider Nephila edulis. Int. J. Biol. Macromol. 1999, 24(2), 243-249. 
TABLE 1 The repetitive amino acid sequences of the spider silk proteins.

\begin{tabular}{|c|c|}
\hline Name & repetitive amino acid sequences \\
\hline $11 \mathrm{R} 26$ & $\underline{\mathbf{S}}$ GRGGLGGQGAGAAAAAGGAGQGGYGGLGSQQG \\
\hline $\mathrm{ZF} 4$ & 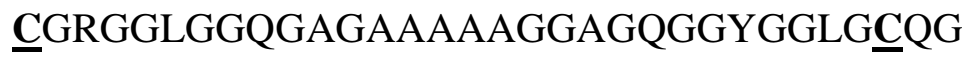 \\
\hline ZF5 & 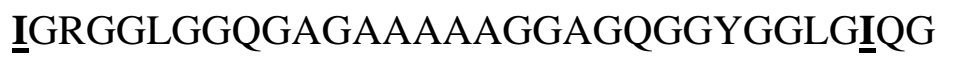 \\
\hline ZF6 & RGRGGLGGQGAGAAAAAGGAGQGGYGGLGRQG \\
\hline
\end{tabular}

11R26 was the wild type spider silk protein, the underline and bold serine (S) was chosen as the mutant sites; in $\mathrm{ZF}$ 4, the repetitive amino acid sequence was mutated to cysteine (C) from serine (S), in ZF5, isoleucine (I) from serine (S); in ZF6, arginine (R) from serine $(\mathrm{S})$. 
FIGURE 1 Purification of proteins expressed in BL21 (pET30a-11R26/ZF4/ZF5/ZF6) with 6 His tag by Ni affinity column. (Lane 1: 11R26; lane2: ZF4; lane 3: ZF5; lane 4: ZF6; Lane 5: filted protein; Lane M: protein marker).

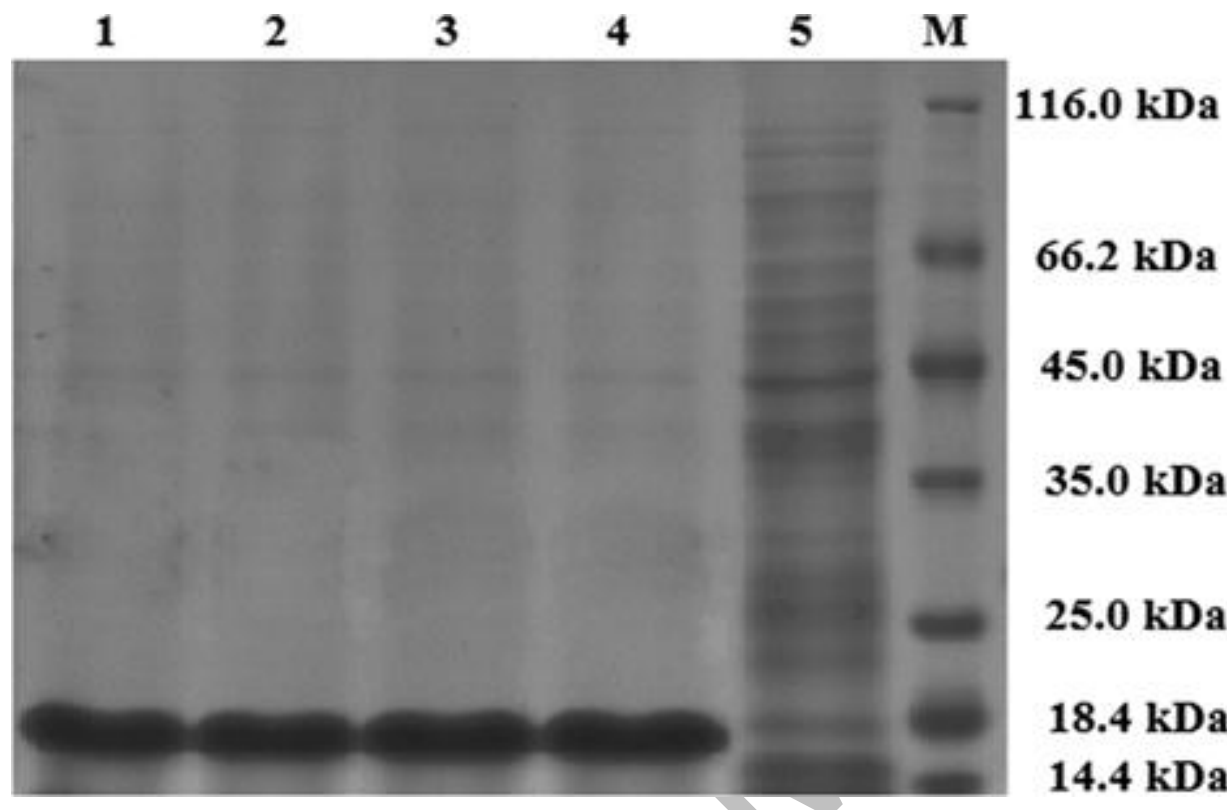


FIGURE 2 Electrospinning and scanning of spider silk with different concentrations.

The purified protein was dialyzed with $\mathrm{ddH}_{2} \mathrm{O}$, freeze-drying and dissolved in HFIP at the concentrations of $50 \mathrm{mg} / \mathrm{mL}, 80 \mathrm{mg} / \mathrm{mL}$ and $100 \mathrm{mg} / \mathrm{mL}$ at $50^{\circ} \mathrm{C}$ for $12 \mathrm{~h}$ and then injected in a $1 \mathrm{~mL}$ syringe and manufactured by electrospinning. A: $50 \mathrm{mg} / \mathrm{mL}$; B: 80 $\mathrm{mg} / \mathrm{mL} ; \mathrm{C}: 100 \mathrm{mg} / \mathrm{mL}$.

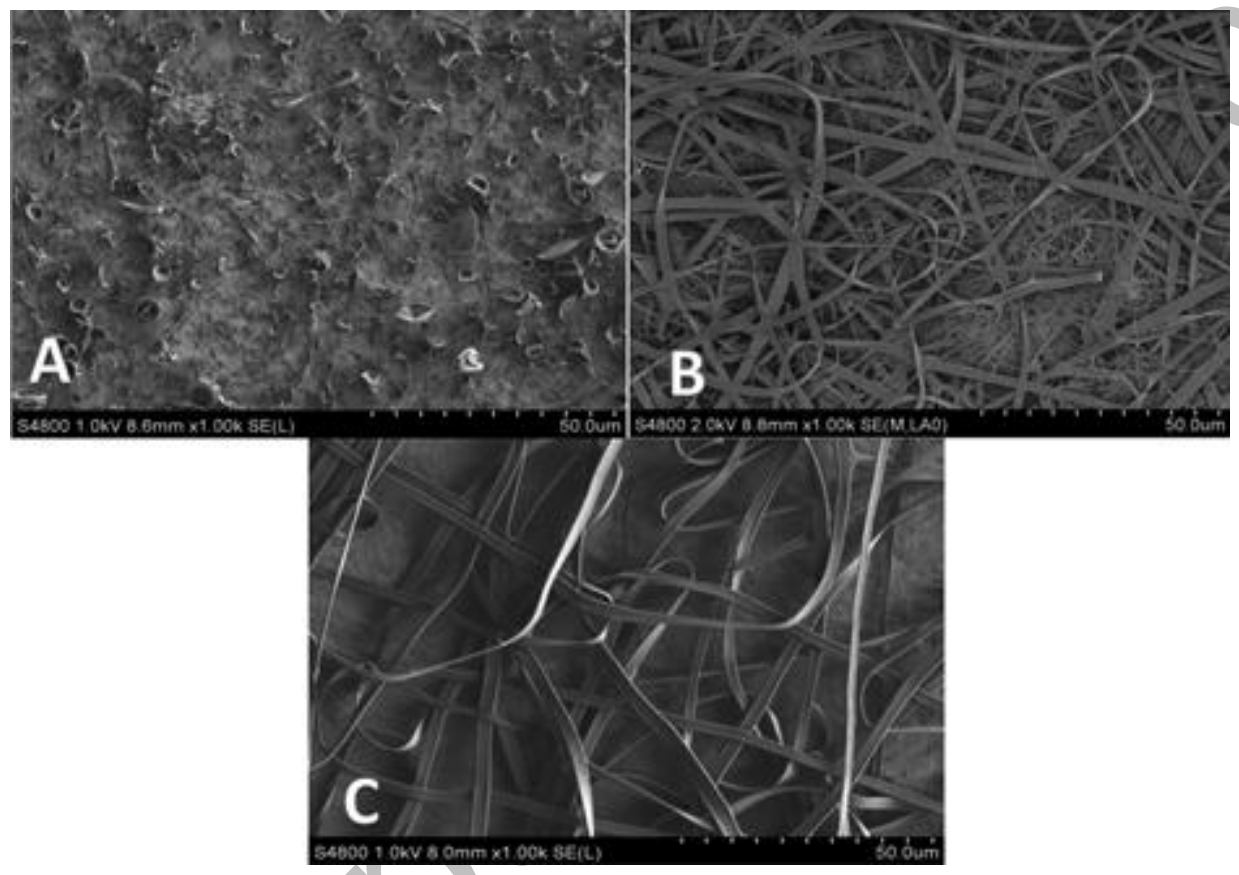


FIGURE 3 Force curves of four kinds of silk (hardness test).A: 11R26, the maxmium response value was $10 \mathrm{nN}$; B: ZF4, the maxmium response value was $32 \mathrm{nN}$; $\mathrm{C}: \mathrm{ZF}$, the maxmium response value was $11 \mathrm{nN}$; D: ZF6, the maxmium response value was $13 \mathrm{nN}$.
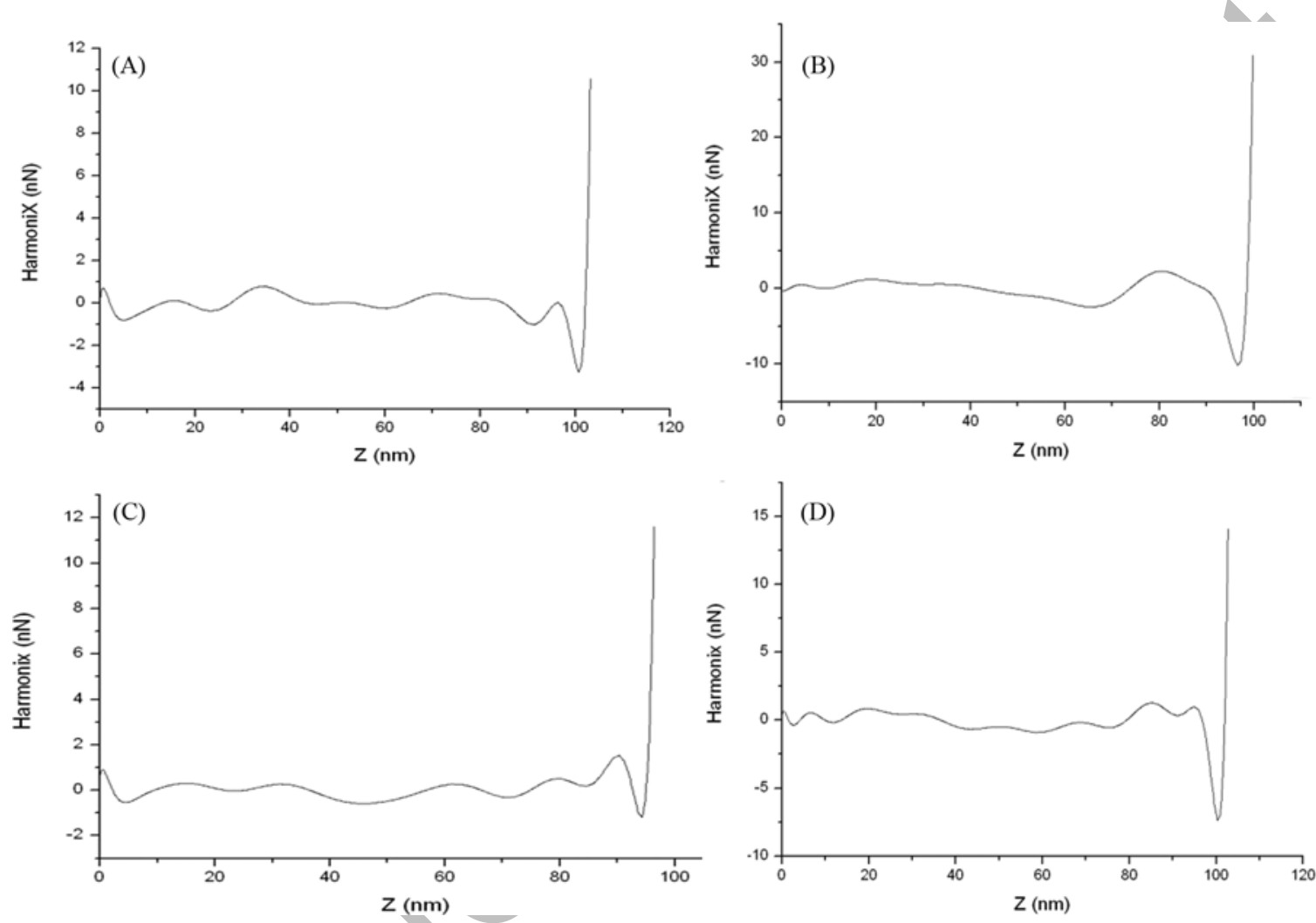
FIGURE 4 Elastic modulus maps of four kinds of silk. A: 11R26, the maximum elastic modulus was about $1.385 \mathrm{GPa}$ and the average was $0.421 \mathrm{GPa}$; B: ZF4, the maximum elastic modulus was about $2.312 \mathrm{GPa}$ and the average was $1.347 \mathrm{GPa}$; C: ZF5, the maximum was $1.307 \mathrm{GPa}$ and the average was $0.913 \mathrm{GPa}$; D: ZF6, the maximum was $1.481 \mathrm{GPa}$ and the average was $0.585 \mathrm{GPa}$.
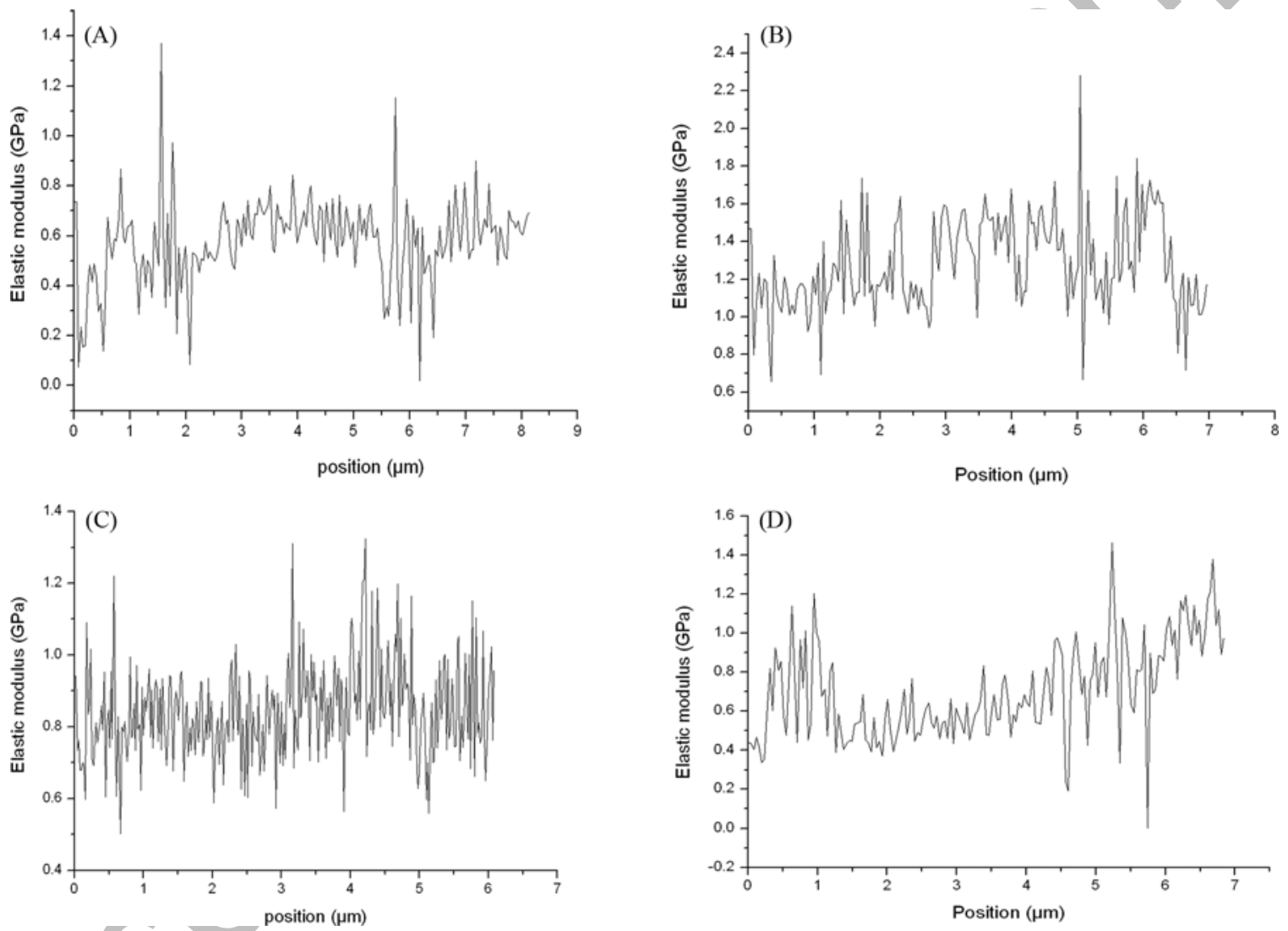


\section{FIGURE 5.}
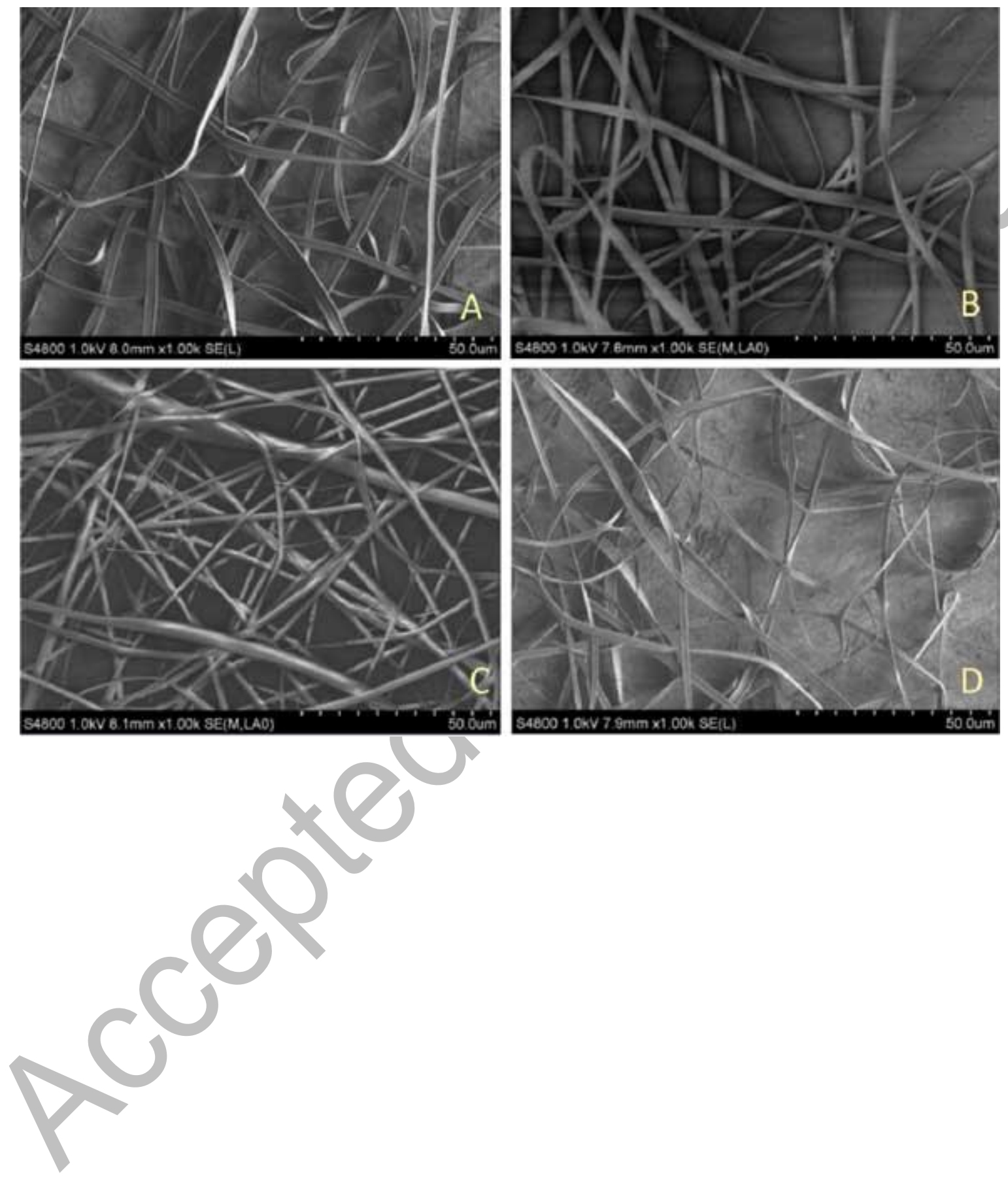